\title{
Book Review: Illness or Person?
}

Beth Z. Mark, M.D.

Thomas Jefferson University, Philadelphia, Pennsylvania

Follow this and additional works at: https://jdc.jefferson.edu/jeffjpsychiatry

Part of the Psychiatry Commons

Let us know how access to this document benefits you

\section{Recommended Citation}

Mark, M.D., Beth Z. (1990) "Book Review: Illness or Person?," Jefferson Journal of Psychiatry. Vol. 8 : Iss. 1 , Article 15.

DOI: https://doi.org/10.29046/JJP.008.1.012

Available at: https://jdc.jefferson.edu/jeffjpsychiatry/vol8/iss1/15

This Article is brought to you for free and open access by the Jefferson Digital Commons. The Jefferson Digital Commons is a service of Thomas Jefferson University's Center for Teaching and Learning (CTL). The Commons is a showcase for Jefferson books and journals, peer-reviewed scholarly publications, unique historical collections from the University archives, and teaching tools. The Jefferson Digital Commons allows researchers and interested readers anywhere in the world to learn about and keep up to date with Jefferson scholarship. This article has been accepted for inclusion in Jefferson Journal of Psychiatry by an authorized administrator of the Jefferson Digital Commons. For more information, please contact: JeffersonDigitalCommons@jefferson.edu. 


\title{
Book Reviews
}

\section{Illness or Person?}

\author{
PSYCHOTHERAPY OF NEUROTIC CHARACTER \\ Dana Shapiro \\ New York, Basic Books, 1989
}

Beth Z. Mark, M.D.

\begin{abstract}
"Freud was seeking the cause of an illness, an intrusion into the personality. The illness was found in the abscess-like dissociated memory; the cause was the trauma. The therapy was catharsis or abreaction, the draining of the abscess. The nature of the therapy was determined by the naure of the condition, perhaps more unequivocally than it was ever to be again"' (pp. 16-17).
\end{abstract}

This, Freud's early model of psychopathology, articulates one side of an internal debate I've had as a second year resident in psychiatry. This inner debate is really a question of where to place the accent or emphasis in the following questions: Do we treat an illness housed in a person (as in the passage above)? Or, do we treat a person who is ill? Where is the primary emphasis? On the person or on the illness? For example, a patient relapses; a six week stay in the hospital is followed by a return there, after two weeks in a transitional living situation. Once back on the unit, she is curled in fetal position and won't feed herself. Am I treating an illness (say, borderline personality disorder)? Or, am I treating a person who characteristically, and to an extraordinary degree, shrinks (or curls up) when faced with something going wrong, difficulties or disappointments. If it is the latter, what set of concepts replaces the illness approach? The "illness" emphasis comes fortified with concepts (e.g., traumatic memories exerting pathogenic influence or reliving traumatic experiences in treatment as the therapeutic agent). Furthermore, as medical residents, we come prepared for the illness approach. I know that after a year's internship in medicine, I had finally begun to think of myself as a doctor. I dealt with illnesses; I treated patients by prescribing some sort of treatment regimen. Maybe it helped, maybe not, but my activity as a doctor, diagnosing illness and prescribing treatment, was never questioned. We are, I believe, less prepared for an approach that emphasizes the person rather than the illness. This person oriented emphasis is further hampered by not having an alternate set of concepts. Such concepts are 
particularly important because without them an emphasis on the person can easily lead to frustration, condemnation, and moralizing about the patient (Why won't she just get up and act like an adult?)

I found David Shapiro's new book, Psychotherapy of Neurotic Character, to provide a fascinating and subtly argued answer to the above issues. Shapiro's "charcterological understanding" of psychopathology and psychotherapy offers an alternative to the more narrow illness conceptualizations, whether they be psychodynamic or biological. Shapiro's conceptualization of character is essentially a holistic approach. Thus, unlike the more conventional psychoanalytic approach to character, examplified by Brenner (1), Shapiro is not interested in isolated "character traits," so much as the organization of an entire personality. Furthermore, unlike Brenner, who is interested in character traits as effects (e.g., character traits as the product of early libidinal history), Shapiro is primarily interested in character as having a basic, causal significance. That is, a person's actions, symptoms, thoughts and feelings are conceived to flow in a direct way from the workings of a particular personality.

Shapiro argues that perhaps the definitive feature of psychopathology is a person's "self-estrangement", i.e., the person is cut off from significant currentsimpulses, thoughts, feelings-in his/her own personality. From this perspective, he offers a fascinating critique of traditional conceptions of psychiatric symptoms, transference, and how a person's history impacts the person.

Shapiro notes that Freud originally viewed neurotic symptoms as peculiar and isolated outcroppings from a basically intact personality. While much has changed in psychoanalytic theory, it is Shapiro's view that this early conception of neurotic symptoms has never been entirely superceded. As previously quoted, "Freud was seeking the cause of an illness, an intrusion into the personality." For example, in the traditional psychoanalytic view, an obsession is considered to be a function of a specific and circumscribed conflict between an impulse and defense. Rather than the product of an isolated conflict, it is Shapiro's view that an obsession flows from a certain sort of personality, e.g., from a person who is overly conscientious and scrupulous about all sorts of things. An obsessive symptom is really an indication of how estranged or cut-off the person has become from his/her thoughts and feelings-so much so that the obsession no longer makes sense to the person suffering with it. It seems to me that Shapiro's conception has immediate, practical therapeutic significance. If we regard our patient's symptoms as products of isolated conflicts, do we not reinforce the patient's sense of helplessness and self-estrangement?

Shapiro argues for an altered conception of transference and the role of early, childhood experience along analogous lines to that regarding neurotic symptoms. Transference, he says, is typically considered to be an intrusion into the adult personality of inappropriate or inaccurate reactions or perceptions from the past. For Shapiro, this is far too simple a view. Rather than isolated fragments of childhood perception or reaction that are emitted in treatment, a person's transferences are, once again, conceived to have their roots in a 
person's character. This difference in conception came home to me recently with a sixty year old woman hospitalized for panic attacks and hypochondriacal obsessions. She reports that she had an extraordinarily domineering mother who not only always told her what to do, but whose solution to any of life's problems was to take pills, and at excessive dosages. After she had been in the hospital for a week, I suggested the most effective treatment regimen might well be to add medication to our talking therapy. In the following week, she was extraordinarily anxious about taking the medication, ruminating about all the possible side effects that might ensue. She asked me at least twenty-five times, what should she do? Should she take the medication or not? What about the side effects? Couldn't something bad happen to her?

While we might agree that something transferential is occurring here, the question is how to conceptualize it. The traditional view might suggest the patient is transferring her image of her mother onto me. She now sees me as someone who is attempting to solve problems (hers? mine? both?) by reaching for medication. Given that her mother was none too careful about dosage, it wouldn't be any wonder that she would be terribly anxious about taking the medication. As a matter of fact, it might not be farfetched to surmise that the patient might have had some traumatic experience in childhood caused by her mother's overmedication of her ("the abcesslike dissociated memory"). In this view of transference, specific images of mother are transferred onto me and discrete, walled-off experiences are revived in the transference.

Shapiro's view orients us quite differently. With her mother as a model, it is not surprising that this patient grew up poorly equipped to deal with life's problems. This was both a cause and a consequence of her constantly looking to a "wiser," more powerful person for guidance and direction. Thus, she asks me over and over what she should do. She is in some way aware of not having developed her skills and potentials; she insisted too frequently and with a pathetically false bravado that she learned to make all her own decisions after a hospitalization for agoraphobia in her twenties. With this dim awareness, it is understandable that she would see the world as a very dangerous place, and that she must constantly scan for potential dangers. Thus, her anxiety is less a response to a discrete event, or even a specific class of events (like taking medication), than an inevitable consequence of her current mode of functioning.

Tarachow (2) suggests "a model interpretation" is in the form of "You react as if I were, etc., etc." In doing so "the real situation is transformed into an as if situation demanding attention and comprehension. The act which brings about this transformation is interpretation". Thus, with the patient discussed above, perhaps the classic psychodynamic transferance interpretation would be: "You seem to be reacting to me as if I'm your mother." In Shapiro's view, it becomes less important for the therapist to draw parallels to mother, than to illuminate her subjective experience. For example, though she suffers constantly from various anxieties, and has obviously been aware of the content of these anxieties 
(e.g., "If I take this medication, I might get cancer."), she had not been aware that she is continuously scanning for danger. I believe this is the sort of enlargement of the patient's experience, "of feelings or attitudes of the patient that are in a certain sense already conscious and actually already within subjective experience, yet are not . . fully articulated or recognized by the patient" ( $p$. 11) which Shapiro asserts have therapeutic benefit. Such awareness, might seem like a small beginning, but Shapiro makes clear that it is in just such short steps that real progress in therapy occurs.

I have covered only a small portion of this book. For example, Shapiro has included a discussion of resistance which I found most helpful. There is much else of great interest and use to the student of dynamic psychotherapy. In short, I highly recommend this book.

\section{REFERENCES}

1. Brenner C: An Elementary Textbook of Psychoanalysis. Garden City, N.Y.: Anchor Press, pp 193-198, 1973

2. Tarachow S: An Introduction to Psychotherapy. New York: International University Press, p 9, 1963 